\title{
ANALISIS KINERJA JURU PUNGUT (KOLEKTOR) RETRIBUSI PELAYANAN PERSAMPAHAN TERHADAP TARGET RETRIBUSI PELAYANAN PERSAMPAHAN PADA DINAS LINGKUNGAN HIDUP KOTA PADANG
}

\author{
Imellia, Febryandhie Ananda \\ Sekolah Tinggi Ilmu Ekonomi KBP \\ Email: imellia0204@gmail.com \\ febryandhie@akbpstie.ac.id
}

\begin{abstract}
ABSTRACK
The problems that occur in the service of solid waste service retribution are the realization of solid waste service fees that do not reach the targets that have been set even though the realization of the monthly increase. The realization of this solid waste service levy has caused a decline in local revenue, not only that the realization of solid waste service fees is able to reach the maximum. Based on the context above, the author conducted a study entitled The Analysis of the Performance of the Garbage Collector in the Environmental Services of Padang City. The purpose of this study was to determine the employment relationship with persuasive service fees on the target of solid waste service levies at the Padang City Environmental Agency. This type of research is research that is classified as a quantitative approach. The data analysis technique used in this study is simple linear regression, with the help of SPSS 23. The research variables that can be used are solid waste service fees. The data used in this study is the monthly solid waste service retribution report from 2015-2017, the sample used in this study is solid waste service retribution from 2015-2017. The performance of solid waste service retribution officers is positive and significant towards the effectiveness of the target of solid waste service retribution because it has a significance value of $0.000<0.05=0$. The Determination Value ( $R$ Square) is 0.404 which means that $40 \%$ is real. Significant and significant level of service wages and retributions to the target of solid waste service fees at the Padang City Environmental Service.
\end{abstract}

Keywords: Performance of retribution interpreter, Target of solid waste service retribution

\section{PENDAHULUAN}

Selain pajak, retribusi merupakan sumber penerimaan daerah yang signifikan. Berbeda dengan pajak, retribusi pada umumnya berhubungan dengan jasa Pemerintah langsung dalam arti bahwa pembayar retribusi akan menerima imbalan secara langsung dari retribusi yang dibayarnya. Oleh sebab itu dapat diartikan bahwa retribusi adalah iuran sebagai pembayaran atas jasa atau pemberian izin tertentu yang khusus disediakan atau diberikan oleh pemerintah 
untuk kepentingan orang pribadi atau badan. (Ananda, Putra, \& Hendrastyo, 2017; Ananda \& Zulvia, 2018)

Dalam upaya meningkatkan Pendapatan Asli Daerah (PAD) untuk membiayai pelaksanaan pembangunan di Kota Padang, Pemerintah telah melakukan berbagai bentuk retribusi daerah, salah satu bentuk retribusi daerah itu adalah mengenai retribusi persampahan yang diatur dalam peraturan daerah Kota Padang Nomor 11 Tahun 2011 (PD-No.11, 2011) tentang retribusi jasa umum. Retribusi pelayanan persampahan merupakan retribusi yang cukup potensial dalam meningkatkan Pendapatan Daerah. Penerimaan pemerintah daerah Kota Padang melalui retribusi kebersihan menunjukkan kurang adanya peningkatan yang berarti bahkan untuk tahun terakhir ini tidak mencapai target yang telah ditetapkan. Padahal jumlah wajib retribusi kebersihan untuk setiap tahunnya mengalami peningkatan. Hal ini dapat menyangkut pada kinerja aparatur pelaksana/kolektor dalam melaksanakan tugasnya memungut retribusi pelayanan persampahan. Jika tidak dilakukan perbaikan akan menjadi masalah pada Pendapatan Daerah.

Berikut data dari Dinas Lingkungan Hidup terlihat bahwa pada tahun anggaran 2015 dengan target dibulan Januari sebesar Rp.98.980.000,- terealisasi sebesar Rp.43.326.000,-, bulan Februari target sebesar Rp.142.486.000,terealisasi sebesar Rp.100.703.500,-, bulan Maret Rp.133.789.000,- terealisasi sebesar Rp.109.023.500,- dan seterusnya. Sedangkan pada tahun 2016 target dibulan Januari sebesar Rp.98.500.000,- terealisasi sebesar Rp.64.540.500,-, bulan Februari target sebesar Rp.135.475.000,- terealisasi sebesar Rp.138.683.000,-, bulan Maret target sebesar Rp.140.805.000,- terealisasi sebesar Rp.119.827.000,dan seterusnya. Dan terakhir ditahun 2017 target dibulan Januari sebesar Rp.127.014.000,- terealisasi sebesar Rp.56.331.000,-, bulan Februari target sebesar Rp.97.489.000,- terealisasi sebesar 140.009.500,-, bulan Maret target sebesar Rp.173.785.000,- terealisasi sebesar Rp.168.980.000,- dan seterusnya.

Beberapa penelitian terdahulu mengenai retribusi daerah terhadap target retribusi menunjukkan hasil yang sama. Menurut Kendala belum tercapainya penerimaan target retribusi pengelolaan sampah secara umum disebabkan oleh faktor aparatur pelaksanaan dan persepsi setiap golongan wajib bayar retribusi (Jamaluddin, 2016) dan (Raga, 2011), Peningkatan penerimaan retribusi harus didukung melalui upaya perbaikan struktur dan system yang baik guna peningkatan efektivitas pemungutan. Jika realisasi penerimaan retribusi semakin besar maka semakin mendekati target yang ditetapkan, maka hal tersebut menunjukkan efektivitasnya makin besar.

Retribusi berdasarkan Undang-undang No.28 Tahun 2009 (UndangUndang, 2009) ialah pemungutan daerah atas pembayaran dari jasa tertentu yang khusus diberikan oleh Pemerintah Daerah guna kepentingan individu atau badan. Menurut (Padang, 2016) retribusi ialah pungutan/iuran daerah untuk pembayaran atas jasa dan pemberian izin tertentu yang telah disediakan oleh Pemda guna keperluan tertentu. Jenis retribusi yang ada:

1. Retribusi Jasa Umum

Jenis retribusi jasa umum diatur dalam UU No. 28 Tahun 2009 Pasal 110 ayat 1 (RI, 2009) yaitu:

a. Retribusi Layanan Kesehatan 
b. Retribusi Layanan Persampahan / Kebersihan

c. Retribusi Penggantian Beban Cetak Kartu Tanda Penduduk atau Akta Catatan Sipil

d. Retribusi Layanan Pemakaman

e. Retribusi Layanan Parkir di Jalanan Umum

f. Retribusi Layanan Pasar

g. Retribusi Pengujian Kendaraan Bermotor

h. Retribusi Pemeriksaan Alat Pemadam Kebakaran

i. Retribusi Penggantian Biaya Cetak Peta

j. Retribusi Penyediaan dan lumpur tinja

k. Retribusi Pengolahan Limbah Cair

1. Retribusi Layanan Tera / Tera Ulang

m. Retribusi Layanan Pendidikan

n. Retribusi Pengurusan Menara Telekomunikasi.

\section{Retribusi Jasa Usaha}

Retribusi Jasa Usaha ialah pelayanan yang telah dilayani oleh Pemerintah dengan memegang azas perdagangan seperti:

1. Layanan menggunakan kekayaan Daerah yang belum pakai dengan optimal.

2. Layanan dari Pemerintah semasa yang belum dilayani secara memadai oleh pihak swasta.

3. Retribusi Perizinan Tertentu

Retribusi perizinan tertentu terdiri dari :

a. Retribusi Izin Mendirikan Bangunan

b. Retribusi Izin Tempat Menjual Minuman Alkohol

c. Retribusi Izin Gangguan

d. Retribusi Izin Angkutan

e. Retribusi Izin Usaha Perikanan/Kelautan

Retribusi Pelayanan Persampahan

Retribusi pelayanan persampahan/kebersihan termasuk jenis retribusi jasa umum. Retribusi pelayanan persampahan/kebersihan yaitu pungutan dari daerah atas pembayaran pelayanan persampahan/kebersihan yang dilakukan pemerintah. Pelayanan Persampahan/kebersihan meliputi proses pengumpulan dan pewadahan dari sumber sampah ke Tempat Penampungan Sementara/Terpadu (TPST) dan juga pengangkutan dari TPS/TPST pada Tempat Pemrosesan Akhir (TPA) untuk dihancurkan agar tidak terjadi pencemaran lingkungan (Daerah, 2016).

Juru Pungut ( Kolektor) Retribusi Pelayanan Persampahan

Menurut (Zurahniyah, 2015) Pemungutan oleh juru pungut, maksudnya pemungutan retribusi kebersihan melalui juru pungut dari Dinas Lingkungan Hidup. Petugas pemungut retribusi mempunyai jasa yang sangat besar untuk mewujudkan realisasi penerimaan retribusi pelayanan persampahan. Yang dimaksud dengan petugas pemungut retribusi pelayanan persampahan adalah petugas pemungut dari Dinas Lingkungan Hidup yang mendapat tugas memungut retribusi pelayanan persampahan kepada masyarakat khusus Komersil dan Non 
Komersil yang menggunakan jasa layanan Dinas Lingkungan Hidup Kota Padang. Layanan yang disediakan oleh Dinas Lingkungan Hidup Kota Padang adalah jasa pengangkutan sampah dari Kontainer atau Tempat Penampungan Sementara (TPS) ke Tempat Pemrosesan Akhir (TPS).

Pelaksanaan pemerintah hanya bisa dilakukan dengan adanya beberapa unsur pendukung diantaranya adalah tersedianya dana yang memadai. Tanpa didukungnya semua program pemerintah tidak dapat dilaksanakan dan itu berarti fungsi pemerintah disuatu negara tidak berjalan secara optimal. Begitu pula dengan pelaksanaan otonomi daerah telah membuat dampak positif yaitu paling tidak dari sudut peningkatan sikap kemandirian daerah dalam usaha menggali untuk sumber dari penerimaan daerah. Untuk meningkatkan Pendapatan Asli Daerah (PAD) pemerintah harus menggali semua sumber-sumber pendapatan daerah diantara yaitu retribusi pelayanan persampahan yang berada di Dinas Lingkungan Hidup Kota Padang. Akan tetapi penerimaan dari retribusi pelayanan persampahan belumlah maksimal.

Kendala belum tercapainya penerimaan target retribusi pengelolaan sampah secara umum disebabkan oleh faktor aparatur pelaksana dan persepsi setiap golongan wajib bayar retribusi (Jamaluddin, 2016). Menurut (Raga, 2006), Peningkatan penerimaan retribusi harus didukung melalui upaya perbaikan struktur dan system yang baik guna peningkatan efektivitas pemungutan. Jika realisasi penerimaan retribusi semakin meningkat maka semakin mendekati target yang ditentukan, maka hal ini membuktikan efektivitasnya makin besar.

Hasil ini menunjukkan bahwa Kinerja juru pungut (Kolektor)retribusi pelayanan persampahan berpengaruh pada target retribusi pelayanan persampahan. Berdasarkan rumusan masalah penelitian dan teori yang mendasari, dapat dirumuskan hipotesis penelitian sebagai berikut:

$\mathrm{H}_{\mathrm{a}}$ : Kinerja juru pungut (kolektor) retribusi pelayanan persampahan berpengaruh signifikan positif terhadap target retribusi pelayanan persampahan

$\mathrm{H}_{\mathrm{o}}$ : Kinerja juru pungut (kolektor) retribusi pelayanan persampahan berpengaruh signifikan negatif terhadap target retribusi pelayanan persampahan

\section{METODE PENELITIAN}

Penelitian ini menggunakan metode kuantitatif. Berdasarkan latar belakang dan kerangka pemikiran yang dikemukakan pada bab sebelumnya, maka yang menjadi objek penelitian ini adalah variable $\mathrm{X}$ (Kinerja juru pungut retribusi) dan variable $\mathrm{Y}$ (Target retribusi pelayanan persampahan).

Dalam penelitian ini, penulis memilih lokasi di pada Dinas Lingkungan Hidup Kota Padang, yang berlokasi di Jln. Rambutan Balai Baru Kel.Gunung Sariak Kec. Kuranji Padang.Karena penulis menganggap bahwa lokasi tersebut sangat cocok dengan ruang lingkup penelitian yang penulis lakukan.Penetapan tempat penelitian pada lokasi ini didasarkan pada pertimbangan bahwa obyek tersebut dapat memberikan keterangan yang lengkap tentang masalah yang diteliti yakni data yang diperlukan cukup memadai, dan lokasi tersebut mudah dijangkau sehingga dari segi waktu, biaya dan tenaga cukup menunjang bagi penulis. 
Jenis data yang penulis gunakan dalam penelitian ini adalah data rasio yaitu ukuran yang memberikan keterangan tentang nilai absolute dari objek yang diukur. Sumber data yang digunakan dalam penelitian ini adalah Data Sekunder yaitu data yang diperoleh dari Dinas Lingkungan Hidup dalam bentuk yang sudah jadi dan tidak memerlukan olahan-olahan lagi yaitu Laporan realisasi retribusi per bulan dari Tahun 2015-2017.

Teknik pengumpulan data merupakan langkah-langkah yang paling utama dalam penelitian, karena tujuan utama penelitian adalah mendapatkan data. Teknik pengumpulan data pada penelitian adalah metode Observasi . Dokumen merupakan catatan peristiwa yang sudah berlalu. Dokumen yang digunakan peneliti disini berupa laporan realisasi penerimaan retribusi pelayanan persampahan per bulan dari tahun 2015-2017.

\section{Teknik Analisa Data \\ Uji Asumsi Klasik}

\section{Uji Normalitas}

Uji Normalitas data merupakan syarat pokok yang harus dipenuhi dalam analisis parametric. Normalitas data merupakan hal yang penting karena data yang terdistribusi normal dianggap dapat mewakili populasi (Priyatno, 2014). Pengujian ini dapat dilakukan dengan cara:

Kolmogorov Smirnov

Pengujian dengan ini akan menunjukkan bahwa data terdistribusi normal ketika nilai sig > 0,05 dan sebaliknya ketika nilai sig < 0,05 maka dapat disimpulkan bahwa data tidak terdistribusi normal.

\section{Uji Linearitas}

Uji Linearitas digunakan untuk mengetahui linearitas data apakah dua variabel mempunyai hubungan yang linear atau tidak. Pengujiannya pada SPSS menggunakan Test For Linearity pada taraf signifikansi 0,05. Dua variabel dikatakan mempunyai hubungan yang linear bila signifikansi (Linearity) kurang dari 0,05 (Priyatno, 2014)

Persamaan regresi liniar sederhana yang terbentuk pada satu prediktor adalah :

$$
\begin{aligned}
& \mathrm{TR}=\mathrm{a}+\mathrm{bK}+\mathrm{e} \\
& \text { Keterangan : } \\
& \mathrm{TR} \quad=\text { Target Retribusi Pelayanan Persampahan } \\
& \mathrm{a} \quad=\text { Nilai Konstanta } \\
& \mathrm{b} \quad=\text { Nilai Koefisien Regresi } \\
& \mathrm{K} \quad=\text { Kinerja Juru Pungut (Kolektor) Retribusi } \\
& \mathrm{e} \quad=\text { Error }
\end{aligned}
$$

\section{Uji Autokorelasi}

Autokorelasi merupakan korelasi antara anggota observasi yang disusun menurut waktu dan tempat. Model regresi yang baik seharusnya tiak terjadi autokorelasi. Metode yang digunakan adalah Durbin Watson 
(DW Test) (Priyatno, 2014):

Pengambilan keputusan Uji Durbin Watson adalah sebagai berikut (Priyatno, 2014):

1. DU $<$ DW $<4-$ DU maka $\mathrm{H}_{\mathrm{o}}$ diterima, artinya tidak terjadi autokorelasi.

2. DW < DL atau DW > $4-$ DL maka $\mathrm{H}_{\mathrm{o}}$ ditolak, artinya terjadi autokorelasi.

3. DL $<$ DW $<$ DU atau $4-$ DU $<$ DW $<4-$ DL, artinya tidak ada kepastian atau kesimpulan yang pasti.

Nilai DU dan DL dapat diperoleh dari tabel statistic Durbin Watson.

\section{Uji Hipotesis}

Secara statistic merupakan ketepatan fungsi regresi dalam menaksirkan nilai aktual dapat diukur melalui koefisien determinasi, nilai statistik F dan nilai satistik t. Dimana perhitungannya dapat dikatakan signifikan secara statistic apabila uji nilai statistiknya berada dalam daerah kritis (daerah dimana Ho ditolak). Sedangkan sebaliknya disebut tidak signifikan apabila uji nilai statistiknya berada dalam daerah dimana Ho diterima.

\section{Uji T}

Pengujian ini bertujuan untuk mengetahui apakah variabel independen secara parsial berpengaruh terhadap variabel dependen. Menggunakan significance level 0,05. Jika significance level berada diatas 0,05 maka $\mathrm{H}_{0}$ diterima atau dapat diartikan bahwa variabel independen tidak berpengaruh terhadap variabel dependen. Sebaliknya ketika significance level berada dibawah 0,05 maka $\mathrm{H}_{0}$ ditolak, dapat disimpulkan bahwa variabel independen berpengaruh terhadap variabel dependen (Priyatno, 2014).

\section{Uji Koefisien determinasi $\left(\mathbf{R}^{\mathbf{2}}\right)$}

Koefisisien Determinasi digunakan untuk mengetahui hubungan antara semua variabel independen $(\mathrm{x})$ dan variabel dependen $(\mathrm{y})$. Koefisien Determinasi menunjukkan seberapa besar persentasi variasi dalam variabel dependen yang dapat dijelaskan oleh variasi variabel independen. Angka ini berbentuk persen yang artinya persentase sumbangan pengaruh variabel independen terhadap variabel dependen. Sedangkan sisanya dipengaruhi oleh variabel lain yang tidak dimasukkan dalam model ini.

\section{Definisi Operasional Variabel}

\begin{tabular}{|c|l|l|l|}
\hline Variabel & \multicolumn{1}{|c|}{ Konsep Variabel Skala } & \multicolumn{1}{|c|}{ Skala } \\
& & & Pengukuran \\
\hline Kinerja Juru & Menurut (Dewi, 2013) Petugas & Rasio & Realisasi \\
Pungut & pemungut mempunyai & & Retribusi \\
pelayanan \\
Kolektor) & kontribusi yang sangat besar & & persampaha \\
retribusi & untuk mewujudkan realisasi & & $\mathrm{n}$ \\
pelayanan & penerimaan retribusi. Adapun & & \\
persampahan & yang dimaksud dengan petugas & & \\
\hline
\end{tabular}




\begin{tabular}{|c|l|l|l|}
\hline$(\mathrm{X})$ & $\begin{array}{l}\text { pemungut retirbusi merupakan } \\
\text { orang atau petugas pemungut } \\
\text { yang mndapat tugas memungut } \\
\text { retribusi . (Zurahniyah, 2015) } \\
\text { Menurut } \\
\text { Pemungutan oleh juru pungut, } \\
\text { yaitu pemungutan retribusi } \\
\text { kebersihan melalui juru pungut } \\
\text { dari Dinas Lingkungan Hidup }\end{array}$ & & \\
\hline $\begin{array}{c}\text { Target } \\
\text { retribusi } \\
\text { pelayanan } \\
\text { persampahan } \\
\text { (Y) }\end{array}$ & $\begin{array}{l}\text { Pungutan daerah sebagai } \\
\text { pembayaran atas jasa atau } \\
\text { pemberian izin tertentu yang } \\
\text { khusus oleh Pemerintah Daerah } \\
\text { untuk kepentingan pribadi atau } \\
\text { badan. Menurut (Rinny, 2011). }\end{array}$ & Rasio & $\begin{array}{l}\text { Target } \\
\text { retribusi } \\
\text { pelayanan } \\
\text { persampaha } \\
\text { n per bulan }\end{array}$ \\
& & & \\
\hline
\end{tabular}

\section{HASIL DAN PEMBAHASAN}

\section{Hasil Uji Normalitas}

\begin{tabular}{|l|c|}
\hline & $\begin{array}{c}\text { Standardized } \\
\text { Residual }\end{array}$ \\
\hline Asymp. Sig. (2-tailed) & $0,166^{\mathrm{c}, \mathrm{d}}$ \\
\hline
\end{tabular}

a. Test distribution is Normal.

Dari tabel diatas dapat dilihat bahwa hasil uji menyatakan bahwa nilai Asymp. Sig. (2-tailed) sebesar 0,166 lebih besar dari 0,05 sehingga dapat disimpulkan bahwa data yang diuji berdistribusi normal. Dengan demikian asumsi klasik tentang data berdistribusi normal telah dipenuhi.

\section{Hasil Uji Linearitas}

\begin{tabular}{|l|r|}
\hline \multicolumn{1}{|c|}{ Variabel } & \multicolumn{1}{|c|}{ Koefisien Regresi } \\
\hline Konstanta & 99367506,277 \\
\hline Kinerja Juru Pungut (Kolektor) X & 0,352 \\
\hline
\end{tabular}

Berdasarkan tabel diatas maka ringkasan hasil pengujian dapat diformulasikan persamaan regresinya sebagai berikut:

$$
\begin{array}{ll}
\mathrm{Y} & =\mathrm{a}+\mathrm{Bx}+\mathrm{e} \\
\mathrm{TR} & =99367506,277+0,352 \mathrm{~K}+e \\
\mathrm{TR} & =\text { Target Retribusi Pelayanan Persampahan } \\
\mathrm{K} & =\text { Kinerja Juru Pungut Retribusi (Kolektor) }
\end{array}
$$




$$
E \quad=\text { Error }
$$

Dari persamaan tersebut dapat ditarik kesimpulan bahwa, konstanta menunjukkan tanpa variabel Kinerja Juru Pungut (Kolektor) retribusi pelayanan persampahan sebesar nilai konstanta yang dihasilkan yaitu 99367506,277. Namun jika ada variabel Kinerja juru pungut (Kolektor) retribusi pelayanan persampahan maka Target retribusi pelayanan persampahan akan meningkat disebabkan variabel Kinerja juru pungut (Kolektor) retribusi pelayanan persampahan memberikan pengaruh terhadap Target retribusi pelayanan persampahan.

\section{Hasil Uji Autokorelasi}

\begin{tabular}{|l|l|l|l|l|}
\hline \multicolumn{1}{|c|}{ Variabel } & DW & DU & 4 - DU & Kesimpulan \\
\hline Variabel X & & & & \\
dan Y ( & & & & \\
$\begin{array}{l}\text { Kinerja Juru } \\
\text { Pungut }\end{array}$ & & & & \\
$\begin{array}{l}\text { Retribusi dan } \\
\text { Target } \\
\text { Retribusi } \\
\text { Pelayanan } \\
\text { Persampahan) }\end{array}$ & 2,006 & 1,5245 & 2,4755 & $\begin{array}{l}\text { Tidak terjadi } \\
\text { Autokorelasi }\end{array}$ \\
\hline
\end{tabular}

Nilai Durbin-Watson digunakan untuk mengukur seberapa jauh atau seberapa besar hubungan antara variabel independen dengan variabel dependen. Berdasarkan tabel diatas diperoleh nilai Durbin-Watson sebesar 2,006. Dilihat dari tabel DW didapat dari nilai DU yaitu 1,5245 dan nilai 4-DU adalah 2,4755 maka sesuai dengan rumus uji autokorelasi 1,5245 $<2,006<2,4755$. Dapat disimpulkan bahwa tidak terjadi masalah autokorelasi pada penelitian ini dan penelitian dapat dilanjutkan.

\section{Hasil Uji T}

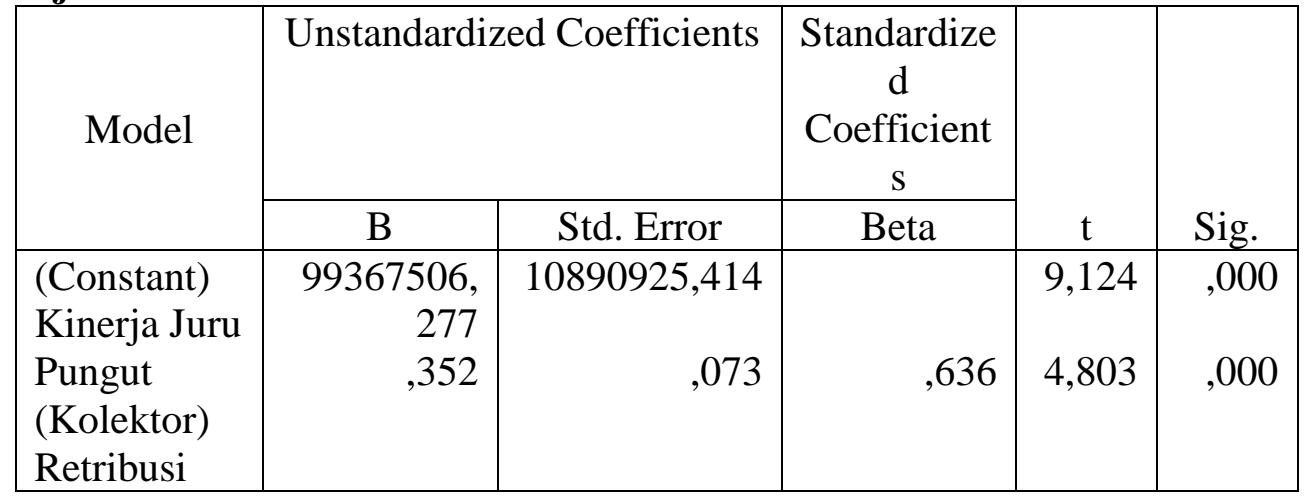

a.Dependent Variable: Y Target Retribusi Pelayanan Persampahan

b.Sumber: Data Sekunder diolah dengan SPSS 23

Dari tabel diatas diketahui diperoleh nilai hitung untuk variabel Target retribusi 4,803 dengan signifikansi 0,005. Nilai Sig variabel Kinerja Juru Pungut (Kolektor) ( $\mathrm{X})$ sebesar $0,000<0,05=0$ maka Ha diterima, berarti terdapat 
pengaruh yang signifikan antara Kinerja Juru Pungut Retribusi Pelayanan Persampahan (X) terhadap Target Retribusi Pelayanan Persampahan (Y).

\section{Hasil Koefesien Determinasi (RSquare)}

\begin{tabular}{|c|c|c|c|c|}
\hline Model & $\mathrm{R}$ & R Square & $\begin{array}{c}\text { Adjusted R } \\
\text { Square }\end{array}$ & $\begin{array}{c}\text { Std.Error of the } \\
\text { estimate }\end{array}$ \\
\hline 1 &, $636^{\mathrm{a}}$ &, 404 &, 387 & 22748298,44797 \\
\hline
\end{tabular}

a. Predictors: (Constant), X Kinerja Juru Pungut (Kolektor) Retribusi

b. Dependent Variable: Y Target retribusi

Berdasarkan tabel diatas maka ringkasan hasil korelasi dan determinasi adalah sebagai berikut:

$\mathrm{R}$ Square $=0,404$ berarti $40,4 \%$ dari variasi nilai variabel Kinerja Juru Pungut (Kolektor) Retribusi sedangkan sisanya 59,6\% dijelaskan oleh variabelvariabel lain yang tidak diteliti dalam penelitian ini.

\section{SIMPULAN}

Berdasarkan analisa data, interpretasi hasil penelitian, dan pembahasan yang telah disampaikan sebelumnya, maka dapat dikemukakan beberapa kesimpulan dari hasil penelitian ini yaitu seluruh variabel dalam penelitian ini berdistribusi normal dibuktikan dengan nilai asymp.sig ( 2 tailed) besar dari 0.05 yaitu sebesar 0,166. Persamaan regresi linear sederhana dalam penelitian ini yaitu $\mathrm{y}=99367506,277+0,352 \mathrm{~K}+e$. Variabel Kinerja Juru Pungut (Kolektor) Retribusi Pelayanan Persampahan berpengaruhi signifikan terhadap Target Retribusi Pelayanan Persampahan yang dibuktikan dengan nilai signifikansi $<0,05$ yaitu sebesar 0,000. Dengan nilai signifikansi $0,000<0,05=0$, maka Ha diterima, berarti terdapat pengaruh yang signifikan antara variable Kinerja Juru Pungut Retribusi Pelayanan Persampahan (X) terdapat Target Retribusi Pelayanan Persampahan (Y).

\section{UCAPAN TERIMA KASIH}

Syukur Alhamdulillah penulis ucapkan kepada Allah SWT, yang telah memberikan rahmat dan hidayah-Nya, sehingga akhirnya penulis dapat menyelesaikan Penelitian ini dengan judul "Analisis Kinerja Juru Pungut (Kolektor) Retribusi Pelayanan Persampahan Terhadap Target Retribusi Pelayanan Persampahan“.

Oleh karna itu dalam kesempatan ini penulis ingin mengucapkan terima kasih yang sebesar - besarnya kepada :

1. Bapak Febryandhie Ananda, SE, M.Si, selaku Ketua STIE KBP sekaligus dosen pembimbing dalam pembuatan skripsi ini yang telah memberikan pengarahan dan saran serta dorongan yang sangat berarti bagi penulis dalam penyelesaian skripsi ini.

2. Ibuk Lidya Marta, SE, MM, selaku wakil Ketua STIE KBP.

3. Ibuk Dewi Zulvia, SE, MM. selaku Pembimbing Akademik yang juga memberikan pengarahan dan saran bagi penulis. 
4. Bapak H.AL Amin,SE,MM, selaku Kepala Dinas Lingkungan Hidup Kota Padang dan Bapak Deni Harzandy,S.Sos selaku Kabid. Pengelolaan Sampah dan Kebersihan beserta Staf dan Petugas Juru Pungut Retribusi yang telah memberikan izin tempat bagi penulis untuk melakukan penelitian.

\section{DAFTAR PUSTAKA}

Ananda, F., Putra, R. D., \& Hendrastyo, V. S. (2017). Kesuksesan Implementasi System Application Product (SAP) studi kasus di PT. Semen Padang. Jurnal Pundi, 1(1), 1-10. https://doi.org/10.31575/jp.v1i1.4

Ananda, F., \& Zulvia, D. (2018). Indikasi machiavellianism dalam pembuatan keputusan etis auditor pemula. Benefita, 3(September), 357-369. https://doi.org/10.22216/jbe.v3i3.3660

Daerah, P. (2016). Peraturan Daerah Kota Padang Nomor 1 Tahun 2016. Padang.

Dewi, O. C. (2013). Retribusi Pasar Di Kabupaten Sleman Tahun 2006 - 2010.

Jamaluddin, Y. (2016). Implementasi kebijakan tarif jasa pengelolaan sampah di kota bandung, 1 (November), 16-24.

Padang, P. D. K. (2016). Peraturan Daerah Walikota Padang Nomor 1 Tahun 2016 tentang Perubahan Kedua Atas Peraturan Daerah Kota Padang Nomor 11 Tahun 2011 tentang Retribusi Jasa Umum. Padang.

PD-No.11. (2011). Peraturan Daerah Kota Padang Tentang Retribusi Jasa Umum. Peraturan Daerah, 2008.

Priyatno, D. (2014). SPSS 22 : Pengolahan Data Terpraktis.

Raga, A. W. (2006). Analisis Kinerja Penerimaan Retribusi Pasar Di Kabupaten Demak.

Raga, A. W. (2011). Analisis Kinerja Penerimaan Retribusi Pasar Di Kabupaten Demak Tahun 2006-2009.

RI, U. (2009). UNDANG-UNDANG REPUBLIK INDONESIA NOMOR 28 TAHUN 2009 TENTANG PAJAK DAERAH DAN RETRIBUSI DAERAH.

Rinny, A. (2011). Analisis Implementasi Kebijakan Retribusi Kebersihan dan Kontribusinya Terhadap Peningkatan PAD Di Kota BAUBAU.

Undang-Undang. (2009). Undang-Undang Republik Indonesia Nomor 28 Tahun 2009 Tentang Pajak Daerah Dan Retribusi Daerah.

Zurahniyah, A. (2015). Kontribusi Pemungutan Retribusi Kebersihan Terhadap Peningkatan Pendapatan Asli Daerah (PAD) Kota Malang, (3). 